\title{
INFLUENCE OF WELDING TECHNOLOGY ON THE STRUCTURE, MECHANICAL PROPERTIES AND FRACTURE TOUGHNESS OF 09G2S STEEL WELDED JOINTS
}

\author{
Yu. N. Saraev ${ }^{1}$, S. V. Gladkovsky ${ }^{2}$, S. V. Lepikhin ${ }^{2 *}$, D. A. Dvoynikov², \\ I. S. Kamantsev ${ }^{2}$, V. E. Veselova ${ }^{2}$ \\ ${ }^{1}$ Institute of Strength Physics and Materials Science, Siberian Branch of the Russian Academy of Sciences, \\ 2/4 Akademicheskii Ave., Tomsk, Russian Federation \\ ${ }^{2}$ Institute of Engineering Science, Ural Branch of the Russian Academy of Sciences, \\ 34 Komsomolskaya St., Ekaterinburg, Russian Federation \\ *Corresponding author. E-mail: 1sv@imach.uran.ru \\ Address for correspondence: ul. Komsomolskaya, 34, 620049, Ekaterinburg, Russian Federation \\ Tel.: +7 (343) 36234 48; fax: +7 (343) 3745330
}

The effect of direct current welding and adaptive pulse welding with current modulation on the structure and mechanical properties of a 09G2S steel welded joint under tensile and impact bending testing, as well as on its static, dynamic and cyclic crack resistance characteristics (fracture toughness), is comparatively evaluated. The efficiency of using the welding process with current modulation to increase the brittle fracture resistance of products and structural components made of low-carbon steel to operate in low-temperature climates is shown.

Keywords: welded joints, weld metal, heat-affected zone, pulse arc welding, microstructure, residual stresses, impact strength, fracture toughness.

DOI: $10.17804 / 2410-9908.2017 .5 .023-042$

\section{References}

1. Grabin V.F., Denisenko A.V. Metallovedeniye Svarki Nizko- i Srednelegirovannykh Staley [Material Science of Welding Low- and Medium-Alloy Steels]. Kiev, Naukova Dumka Publ., 1978, 256 p. (In Russian).

2. $\quad$ Livshits L.S., Khakimov A.N. Metallovedeniye Svarki i Termicheskaya Obrabotka Svarnykh Soyedineniy [Material Science of Welding and Heat Treatment of Welded Joints]. Moscow, Mashinostroenie Publ, 1989, 336 p. (In Russian).

3. Makhutov N.A., Lyglayev A.V., Bolshakov A.M. Khladostoykost (Metod Inzhenernoy Otsenki) [Cold Resistance (Engineering Evaluation Method)]. Novosibirsk, SB RAS Publ., 2011, 195 p. (In Russian).

4. Goritsky V.M. Primeneniye Kharakteristik Udarnoy Vyazkosti v Inzhenernoy Praktike [Application of Fracture Toughness Characteristics in Engineering Practice]. Moscow, Metallurgizdat Publ., 2016, 304 p. (In Russian).

5. Saraev Yu.N., Poletika I.M., Kozlov A.V., Khomchenko E.G. Formation of the structure and properties of welds under conditions of heat input during pulse welding Fizicheskaya Mezomekhanika, Spets. Vypusk, 2005, no. 8, pp. 137-140. (In Russian).

6. Gorkunov E.S., Saraev Yu.N., Zadvorkin S.M., Putilova E.A. The effect of technological welding conditions on the physical and mechanical properties of the metal of different zones of low-alloy steel welds. Voprosy Materialovedeniya, 2015, no. 1 (81), pp. 120-126 (In Russian).

7. Saraev Yu.N., Gladkovsky S.V., Golikov N.I., Veselova V.E. Improving the service properties of metal structures working under conditions of low climatic temperatures by methods of adaptive pulsed arc welding. Svarochnoye Proizvodstvo, 2015, no. 11, pp. 33-40. (In Russian).

8. Saraev Yu.N., Bezborodov V.P., Gladovsky S.V., Golikov N.I. Properties of the welded joints of manganese steel made by low-frequency pulsed arc welding. Russian Metallurgy, 2017, no. 4, pp. 287-292. DOI: 10.1134/S0036029517040206 
9. Saraev Yu.N., Bezborodov V.P., Gladovskiy S.V., Golikov N.I. Improving the reliability of metallic structures in service in the conditions with low climatic temperatures by efficient application of advanced methods of modification of the zone of the welded joint. Welding International, 2017, vol. 31, no. 8, pp. 631-636. DOI: 10.1080/09507116.2017.1307512

10. Botvina L.R. Razrusheniye. Kinetika, Mekhanizmy, Obshchiye Zakonomernosti [Fracture. Kinetics, General Regularities]. Moscow, Nauka Publ., 2008, 334 p. (In Russian).

11. Terentiev V.F. Ustalostnaya Prochnost Metallov $i$ Splavov [Fatigue Strength of Metals and Alloys]. Moscow, Intermet Inzhiniring Publ., 2002, 288 p. (In Russian).

12. Rusakov A.A. Rentgenografiya Metallov [X-ray Diffraction of Metals]. Moscow, Atomizdat Publ., 1977, 480 p. (In Russian).

13. Pugacheva N.B., Michurov N.S., Trushina E.B. Peculiarities of the structure of welded aluminum alloy joints. Diagnostics, Resource and Mechanics of materials and structures, 2015, iss. 5, pp. 58-71. Available at: http://dream-journal.org/issues/2015-5/2015-5_43.html

14. Honeycombe R.W.K. Plasticheskaya Deformatsiya Metallov [Plastic Deformation of Metals]. Moscow, Mir Publ., 1972, 408 p. (In Russian). 
Подана в журнал: 19.10 .2017

УДК 621.791.053:620.178.74

DOI: $10.17804 / 2410-9908.2017 .5 .023-042$

\title{
ВЛИЯНИЕ ТЕХНОЛОГИИ СВАРКИ НА СТРУКТУРУ, МЕХАНИЧЕСКИЕ СВОЙСТВА И ХАРАКТЕРИСТИКИ ТРЕЩИНОСТОЙКОСТИ СВАРНЫХ СОЕДИНЕНИЙ ИЗ СТАЛИ О9Г2С
}

\author{
Ю. Н. Сараев ${ }^{1}$, С. В. Гладковский ${ }^{2}$, С. В. Лепихин ${ }^{2 *}$, Д. А. Двойников ${ }^{2}$, \\ И. С. Каманцев ${ }^{2}$, В. Е. Веселова ${ }^{2}$ \\ ${ }^{1}$ Федеральное государственное бюджетное учреждение науки Институт физики прочности \\ и материаловедения Сибирского отделения Российской академии наук, \\ просп. Академический, 2/4, Томск, Российская Федерация \\ ${ }^{2}$ Федеральное бюджетное учреждение науки Институт машиноведения Уральского отделения \\ Российской академии наук, ул. Комсомольская, 34, Екатеринбург, Российская Федераџия \\ *Ответственный автор. Электронная почта: 1sv@imach.uran.ru \\ Адрес для переписки: ул. Комсомольская, 34, Екатеринбург, Российская Федерация \\ Тел.: +7 (343) 362-34-48; факс: +7 (343) 374-53-30
}

Проведена сравнительная оценка методов сварки на постоянном токе и адаптивноимпульсной сварки с модуляцией тока на структуру, механические свойства при испытаниях на растяжение и ударный изгиб, а также характеристики статической, динамической и циклической трещиностойкости (вязкости разрушения) сварного соединения из стали 09Г2С. Показана эффективность использования сварочного процесса с модуляцией тока с целью повышения сопротивления хрупкому разрушению изделий и элементов конструкций из низкоуглеродистой стали для работы в условиях низких климатических температур.

Ключевые слова: сварные соединения, металл шва, зона термического влияния, импульсная дуговая сварка, структура, остаточные напряжения, ударная вязкость, трещииностойкость

\section{1. Введение}

Повышение надежности изделий и элементов конструкций, эксплуатирующихся при низких климатических температурах в условиях Сибири и Крайнего Севера, в значительной степени определяются качеством сварных соединений и уровнем их прочностных и пластических свойств, а также сопротивлением хрупкому разрушению. Известно, что неблагоприятные структурные изменения в околошовной зоне (образование охрупчивающих фаз при полной и частичной закалке, рост зерна в зоне перегрева) могут способствовать снижению пластичности и ударной вязкости сварного соединения, а также образованию горячих и холодных трещин [1-2]. Фазовый состав и структура различных участков сварных соединений в значительной степени зависят и от химического состава свариваемых сталей, и ряда определяемых технологическим процессом сварки факторов, таких как способ сварки и режим сварки, количество проходов и используемые сварочные материалы. Изменяя технологические процессы сварки и вызывая соответствующие изменения скорости охлаждения, можно регулировать соотношение между структурными составляющими и тем самым оказывать влияние на механические свойства сварного соединения. При этом обеспечение надежности и долговечности эксплуатирующихся в условиях Сибири и Крайнего Севера газопроводов, транспортных систем и элементов строительных конструкций со сварными соединениями может достигаться только на основе анализа результатов комплексных стандартных и специализированных испытаний различных участков сварных соединений на одноосное растяже- 
ние, ударную вязкость, статическую, циклическую и динамическую трещиностойкость в широком температурном диапазоне [3-4].

Для выявления возможностей улучшения качества и повышения механических свойств и сопротивления сварных соединений хрупкому разрушению значительный интерес представляют работы, направленные на развитие новых прогрессивных сварочных технологий. Так, в работах [5-9] установлено, что сварные соединения, полученные методом адаптивной импульсной дуговой сварки, вследствие регулируемого тепловложения и интенсивного перемешивания сварочной ванны по однородности и дисперсности структуры значительно превосходят сварные швы, получаемые при стационарном режиме сварки.

Цель работы - изучение влияния режимов адаптивной импульсной дуговой сварки с модуляцией тока (CMT) в сопоставлении с режимами сварки на постоянном токе (СПТ) на механические свойства и характеристики трещиностойкости сварных соединений из низкоуглеродистой стали 09Г2С при различных условиях нагружения.

\section{2. Материал и методика}

Исследованы сварные образцы пластин размером $300 \times 200 \times 6$ мм из конструкционной стали 09Г2С, выполненных ручной дуговой сваркой с применением режима импульсного изменения энергетических параметров с низкочастотной модуляцией тока (CMT) и режима сварки на постоянном токе (СПТ). Сварка производилась в ИФПМ СО РАН на сварочном источнике питания ФЕБ-315 «МАГМА», оснащенном пультом дистанционного режима «Пульс», обеспечивающим реализацию импульсно-дугового процесса сварки. Режимы и параметры сварки образцов приведены в табл. 1.

Таблица 1 - Режимы и параметры сварки пластин из стали 09Г2С

\begin{tabular}{|c|c|c|c|c|}
\hline Серия & $\begin{array}{l}\text { Режим } \\
\text { сварки }\end{array}$ & Параметры тока и напряжения & $\begin{array}{l}\text { Ток имп. } \mathrm{I}_{\mathrm{n}} \text {, } \\
\text { длит. имп. } \mathrm{t}_{\text {и }}\end{array}$ & $\begin{array}{l}\text { Ток паузы } \mathrm{I}_{п} \text {, } \\
\text { длит. паузы } \mathrm{t}_{\text {п }}\end{array}$ \\
\hline 3 & $\mathrm{CMT}$ & $\begin{array}{l}\text { Корень: Ø } 3 \text { мм, УОНИ 13/55: } \\
\text { Ід ср = 74,38 А; Uд ср = 20,4 В. } \\
\text { Заполнение: Ø } 3 \text { мм, УОНИ 13/55: } \\
\text { Ід ср = 74,38 А; Uд ср = 20,4 В }\end{array}$ & $\begin{array}{c}I_{\mathrm{L}}=94 \mathrm{~A}, \\
\mathrm{t}_{\mathrm{L}}=0,012 \mathrm{c}\end{array}$ & $\begin{array}{l}\mathrm{I}_{\Pi}=17,8 \mathrm{~A}, \\
\mathrm{t}_{\Pi}=0,030 \mathrm{c}\end{array}$ \\
\hline 4 & CMT & $\begin{array}{l}\text { Корень: Ø } 3 \text { мм, СЗСМ-01К: } \\
\text { Ід ср = 88,1 А; Uд ср = 19,76 В. } \\
\text { Заполнение: Ø } 3 \text { мм, СЗСМ-01К: } \\
\text { Ід ср = } 88 \text { А; Uд ср = 19,76 В. }\end{array}$ & $\begin{array}{l}\mathrm{I}_{\mathrm{L}}=132 \mathrm{~A}, \\
\mathrm{t}_{\mathrm{H}}=0,014 \mathrm{c}\end{array}$ & $\begin{array}{c}\mathrm{I}_{\Pi}=32 \mathrm{~A}, \\
\mathrm{t}_{\Pi}=0,027 \mathrm{c}\end{array}$ \\
\hline 5 & СПТ & $\begin{array}{l}\text { Корень: Ø } 3 \text { мм, СЗСМ-01К: } \\
\text { Ід = } 80 \text { А; Uд = } 19 \text { В. } \\
\text { Облицовка: Ø } 3 \text { мм, СЗСМ-01К: } \\
\text { Ід = } 93 \text { А; Uд ср = 20,5 В }\end{array}$ & & - \\
\hline
\end{tabular}

Результаты химического анализа стали основы - 09Г2С, проведенного на оптическом эмиссионном спектрометре SPECTROMAXх представлены в табл. 2.

Таблица 2 - Химический состав исследуемой стали 09Г2С

\begin{tabular}{|l|c|c|c|c|c|c|c|c|c|c|}
\hline \multicolumn{10}{|c|}{ Химический состав, мас. \% } \\
\hline Элемент & $\mathrm{Fe}$ & $\mathrm{C}$ & $\mathrm{Si}$ & $\mathrm{Mn}$ & $\mathrm{S}$ & $\mathrm{P}$ & $\mathrm{Cr}$ & $\mathrm{Ni}$ & $\mathrm{As}$ & $\mathrm{Cu}$ \\
\hline Хим. анализ & Осн. & 0,098 & 0,66 & 1,40 & 0,007 & 0,03 & 0,029 & 0,045 & 0,022 & 0,049 \\
\hline ГОСТ 19281-89 & Осн. & $\leq 0,12$ & $0,5-0,8$ & $1,3-1,7$ & $\leq 0,04$ & $\leq 0,035$ & $\leq 0,3$ & $\leq 0,3$ & 0,08 & $\leq 0,3$ \\
\hline
\end{tabular}


Для выявления макроструктуры сварных соединений использовали 50 \%-й раствор соляной кислоты. Макроструктуру изучали при помощи оптического микроскопа МБС-10. При исследовании микроструктуры сварных швов (СШ) зоны термического влияния (ЗТВ) с прилегающими к ней участками основного металла $(\mathrm{OM})$ шлифы подвергали химическому травлению в 3 \%-ном спиртовом растворе азотной кислоты. Микроструктуру исследовали на оптическом микроскопе NEOPHOT-21.Фрактографический и микрорентгеноспектральный анализ изломов проводили на растровом электронном микроскопе TESCAN VEGA II XMU с системой энергодисперсионного микроанализа INCA ENERGY 450. Измерения микротвердости сварных соединений выполняли на микротвердомере SHIMADZU HMV G при нагрузке 490,3 мН (0,05 кгс) с шагом 100 мкм.

Для испытаний на растяжение использовали плоские пропорциональные образцы тип XIII толщиной 5 мм в соответствии с требованиями ГОСТ 6996-66. Испытания на растяжение проводили при комнатной температуре на сервогидравлической универсальной испытательной машине INSTRON 8801 при скорости перемещения подвижного захвата $1 \mathrm{~mm} / \mathrm{Mин} \mathrm{с}$ использованием навесного экстензометра с базой 50 мм. В процессе нагружения образцов с использованием программного обеспечения Bluehill строили кривые растяжения и рассчитывали значения стандартных механических свойств: $\sigma_{\mathrm{B}}, \sigma_{0,2}, \delta$ и $\psi$.

Испытания на ударный изгиб проводили при 20 и минус $60^{\circ} \mathrm{C}$ на стандартных образцах с V-образным надрезом тип X по ГОСТ 6996-66 с использованием инструментированного маятникового копра «Tinius Olsen» IT542, обеспечивающего запись диаграмм ударного нагружения в координатах «нагрузка-перемещение». Надрез наносили по границе усиления и основного металла (перпендикулярно сварному шву). Для испытания при температуре минус 60 образцы охлаждали в смеси жидкого азота и бензина Галоша. Температуру контролировали поверенным термометром ТН-8М. Разделение общей работы разрушения (А) при ударных испытаниях на составляющие ударной вязкости: работу зарождения $\left(\mathrm{A}_{3}\right)$ и работу распространения трещины $\left(\mathrm{A}_{\mathrm{p}}\right)$ проводили на основе анализа экспериментальных диаграмм ударного нагружения в соответствии с рекомендациями ГОСТ 22848-77. Значения параметра динамической трещиностойкости $\left(\mathrm{J}_{1 \mathrm{~d}}\right)$ рассчитывали по формуле, приведенной в работе [10]: $\mathrm{J}_{1 \mathrm{~d}}=2 \mathrm{~A}_{3} / \mathrm{B}(\mathrm{W}-\mathrm{a})$, где $\mathrm{A}_{3}$ - работа зарождения трещины; B - ширина образца; W - высота образца; а - длина концентратора напряжений (надреза).

Создание усталостных трещин и испытания на циклическую трещиностойкость (вязкость разрушения) проводили при комнатной температуре на компактных СТ-образцах $32 \times 30 \times 5$ мм по схеме знакопостоянного внецентренного растяжения с использованием высокочастотной резонансной испытательной машины MIKROTRON $(20 \mathrm{\kappa H})$ в соответствии с рекомендациями РД 50345-82. Частота нагружения составляла 100 Гц, а коэффициент асимметрии цикла соответствовал величине $\mathrm{R}=0,1$. По результатам испытаний строили кинетические диаграммы усталостного разрушения (КДУР) в координатах «скорость роста усталостной трещины - размах коэффициента интенсивности напряжений», линейный участок которых аппроксимировался уравнением Париса [11]. Испытания на статическую трещиностойкость (вязкость разрушения) проводились при комнатной температуре по ГОСТ 25.506-85 на образцах тип 3 с предварительно наведенной усталостной трещиной с использованием испытательной машины INSTRON 8801. Значения показателей прочности, пластичности и ударной вязкости усредняли по результатам испытаний трех идентичных образцов. Разброс значений механических характеристик при испытаниях на растяжение, ударную вязкость, статическую и циклическую трещиностойкость не превышал 5 \%.

Определение остаточных напряжений в отдельных зонах сварного соединения проводили на дифрактометре SHIMADZU XRD-7000 с использованием монохроматизированного Кб-излучения хромового анода. Макронапряжения определяли методом « $\sin ^{2} \psi »[12]$ по линии (211) $\alpha$-фазы в направлении, перпендикулярном шву. Для обеспечения локальности съемки использовали коллиматор диаметром 2 мм. Исследуемый объект снимали при нескольких значениях угла наклона брэгговской плоскости $\psi$ Saraev Yu.N. et al. / Influence of welding technology on the structure, mechanical properties 
к нормали к поверхности объекта. В эксперименте $\psi=0^{\circ} ; 15^{\circ} ; 30^{\circ} ; 45^{\circ}$. Для каждого значения $\psi$ определяли двойной угол дифракции, соответствующий центру тяжести дифракционного максимума линии (211) $\left(2 \theta_{\psi}\right)$. Величину макронапряжений вычисляли по формуле:

$$
\sigma_{\varphi}=\frac{E \cdot \operatorname{ctg} \theta_{0}\left(2 \theta_{0}-2 \theta_{\psi}\right)}{2(1+\mu) \cdot \sin ^{2} \psi},
$$

где $\mu$ - коэффициент Пуассона; $E$ - модуль упругости (модуль Юнга), Па; $2 \theta_{0}$ - центр тяжести рефлекса (211) при $\psi=0 ; 2 \theta_{\psi}$ - центр тяжести линии (211) при наклонной съемке при $\psi=15 \ldots 45^{\circ}$.

Углы дифракции в формуле (1) приведены в радианах.

Исследования структуры и определение механических характеристик сварных соединений из стали 09Г2С проводили на оборудовании, входящем в состав ЦКП «Пластомерия» ИМАШ УрО РАН.

\section{3. Результаты и обсуждение}

Макроструктура сварных соединений исследуемых образцов и распределение микротвердости представлены на рис. 1. Из приведенной макроструктуры сварных соединений и результатов измерения твердости следует, что образец серии 5 (СПТ) характеризуется наибольшей шириной СШ в срединном сечении (около 5 мм). Распределение микротвердости по ширине сварного шва, захватывая зоны термического влияния и основного металла, указывает на незначительные различия между значениями $\mathrm{HV}_{0,05}$ в зависимости от исследуемого участка сварного соединения (рис. 1).

Средние значения микротвердости $\mathrm{HV}_{0,05}$ в исследуемых участках сварных соединений представлены в табл. 3.

Таблица 3 - Средние значения микротвердости в различных зонах сварных соединений

\begin{tabular}{|c|c|c|c|c|}
\hline \multirow{2}{*}{ Серия } & \multirow{2}{*}{$\begin{array}{l}\text { Режим } \\
\text { сварки }\end{array}$} & \multicolumn{3}{|c|}{ Микротвердость $\mathrm{HV}_{0,05}$} \\
\hline & & $\mathrm{OM}$ & $3 \mathrm{~TB}$ & СШ \\
\hline 3 & CMT & \multirow{3}{*}{$237 \pm 4$} & $244 \pm 4$ & $247 \pm 4$ \\
\hline 4 & CMT & & $243 \pm 4$ & $253 \pm 4$ \\
\hline 5 & СПТ & & $243 \pm 4$ & $235 \pm 4$ \\
\hline
\end{tabular}

Микротвердость в зоне СШ и ЗТВ для образцов серии 3 и 4, выполненных в режиме сварки с модуляцией тока, превышает среднее значение микротвердости основного металла. В образцах серии 5 (СПТ) значения микротвердости СШ ниже, чем микротвердость основного металла. Образец серии 4 (СМТ) отличается более высокой твердостью СШ. В ЗТВ исследованные образцы имеют практически одинаковые значения микротвердости $\mathrm{HV}_{0,05}=243-244$. Распределение микротвёрдости для образцов серии 3 (CMT) и 4 (СМT) имеет равномерный характер, в то время как на графике распределения микротвердости образцов серии 5 (СПТ) наблюдаются резкие перепады значений $\mathrm{HV}_{0,05}$ (рис. 1). 

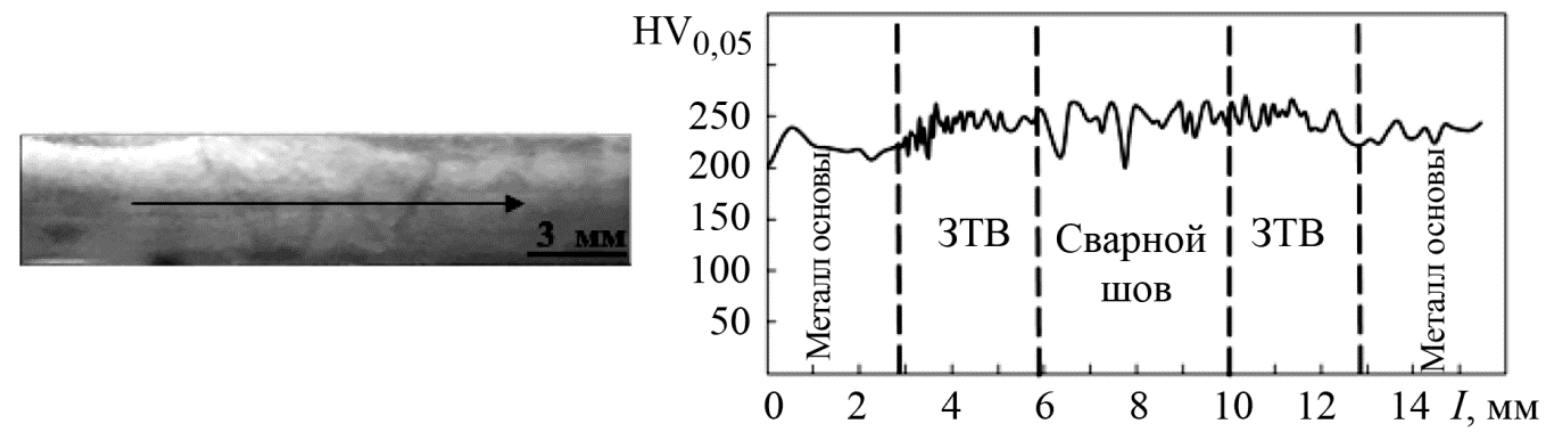

$a$
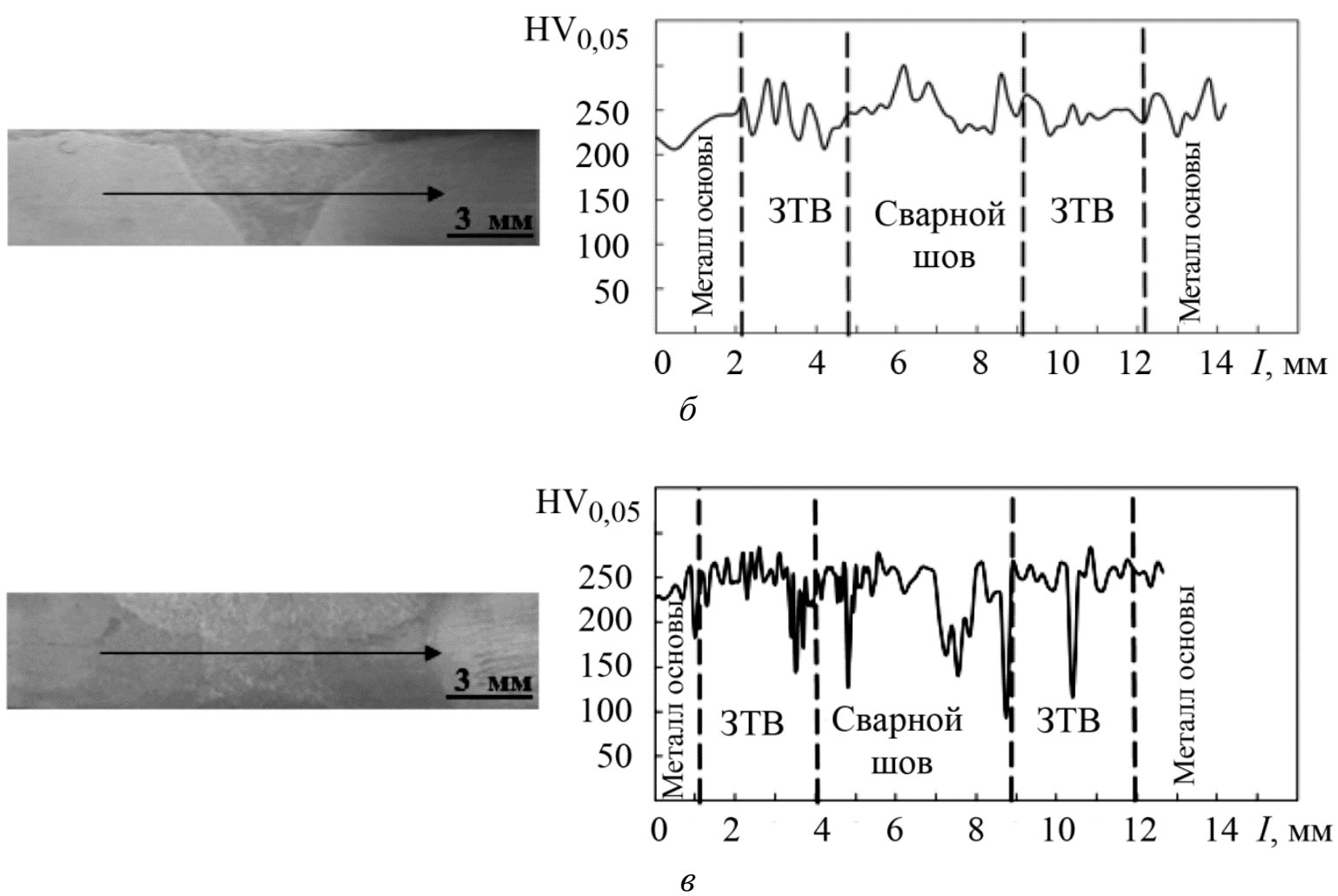

Рис. 1. Макроструктура сварных соединений и распределение микротвердости $\mathrm{HV}_{0,05}$ в образцах серии $3(a), 4$ (б) и 5 (в). Стрелкой указано сечение замера микротвердости

Таким образом, установлено, что импульсно-дуговая сварка по сравнению со сваркой на постоянном токе позволяет получить наиболее однородное распределение значений микротвердости по ширине всех зон сварного соединения стали 09Г2С. Ранее максимально однородное распределение значений микротвердости по ширине всех зон сварного соединения наблюдалось при импульсно-дуговой сварке листа из сплава АМг6 авторами работы [13].

Согласно результатам структурных исследований металл основы представляет собой феррито-перлитную смесь (ФПС) с соотношением объемной доли структурных составляющих в количестве 90/10 (феррит/перлит) (рис. 2). Средний диаметр зерна феррита около 6 мкм. Основной металл имеет однородную полигональную структуру. 


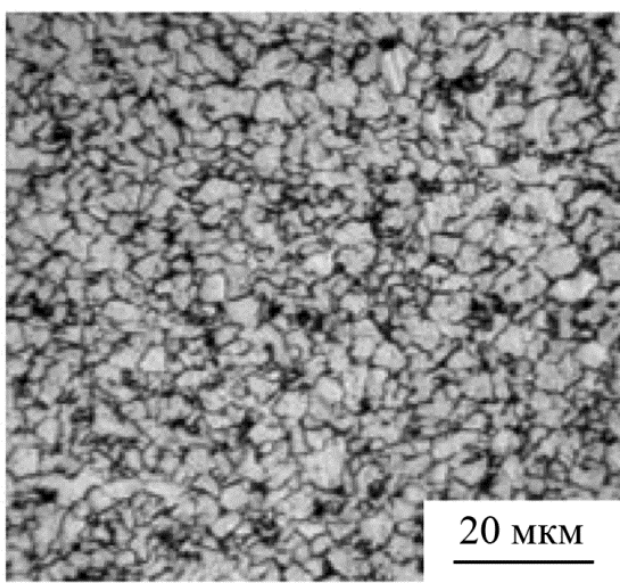

Рис. 2. Микроструктура основного металла

ЗТВ исследуемых сварных соединений состоит из ФПС, которая содержит феррит оскольчатой формы, отдельных участков видманштеттова феррита игольчатой формы и пластинчатого перлита (рис. $3 a, 6, d$ ). Наибольшее содержание феррита данного типа отмечается в образцах серии 4 (СМТ). Средний размер феррита в ЗТВ образцов серий 3 и 4 (СМТ) составляет около 10 мкм. В ЗТВ образца серии 5 (СПТ) отмечается более высокая объемная доля зерен феррита с размером более 12 мкм по сравнению с ЗТВ образцов серий 3 и 4 (СМТ). В целом, дисперсность структурных элементов металла ЗТВ образцов серии 3 и 4 (CMT) примерно в 1,5 раза выше по сравнению с аналогичным участком сварного соединения, полученного по технологии СПТ (образцы серии 5).

Структура СШ образцов серий 3, 4 и 5 представляет собой ФПС: игольчатый и полигональный феррит с пластинчатым перлитом. Полигональный феррит выделился по границам бывших аустенитных зерен в виде цепочек (рис. 3 б, г и e). Наибольший размер игл отмечен в образце серии 3 (до 20 мкм), а наименьший размер игл - в серии 4 (до 5 мкм). Мелкоигольчатый феррит в СШ серии 4 обеспечивает повышенную микротвердость этой зоны в отличие от других образцов (табл. 3). В образце серии 5 (СПТ) размер игл феррита занимает промежуточное значение и составляет 10 мкм при практически равной микротвердости с ОМ (табл. 3).

Проведенные при комнатной температуре испытания сварных соединений стали 09Г2С на одноосное растяжение показали, что разрушение всех исследованных образцов произошло по основному металлу. Согласно представленным в табл. 4 результатам, механические свойства сварных соединений всех изученных серий независимо от технологии сварки различаются незначительно и находятся в пределах $\sigma_{0,2}=455-480 \mathrm{MПа;}$ $\sigma_{\text {в }}=580-590$ МПа; $\delta=22-26,5 \% ; \psi=57,5-59,5 \%$. Прочностные свойства ОМ стали 09Г2С составляют $\sigma_{0,2}=475 \mathrm{MПа;} \sigma_{\text {в }}=585$ МПа и соответствуют уровню прочностных свойств изученных сварных соединений 09Г2С. При этом основной металл характеризуется более высокими пластическими свойствами $\delta=28,5 \%$ и $\psi=60,5 \%$ по сравнению со сварными соединениями (табл. 4).

Как видно из рис. $4 a$, на кривой растяжения основного металла наблюдается выраженная площадка текучести. В то же время, на кривых растяжения всех исследованных образцов сварных соединений стали 09Г2С выявлены скачки нагрузки, характерные для проявления эффекта Портевена-Ле-Шателье [14] (рис. 4 б). Результаты испытаний на растяжение показывают, что при незначительном снижении характеристик пластичности сварных соединений по сравнению с ОМ прочностные свойства находятся на одинаковом уровне. Это свидетельствует о достаточно высоком качестве изученных сварных соединений стали 09Г2С независимо от метода их получения. 


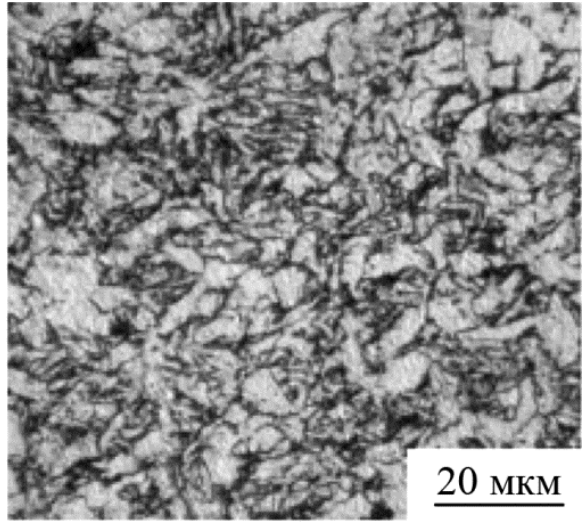

$a$

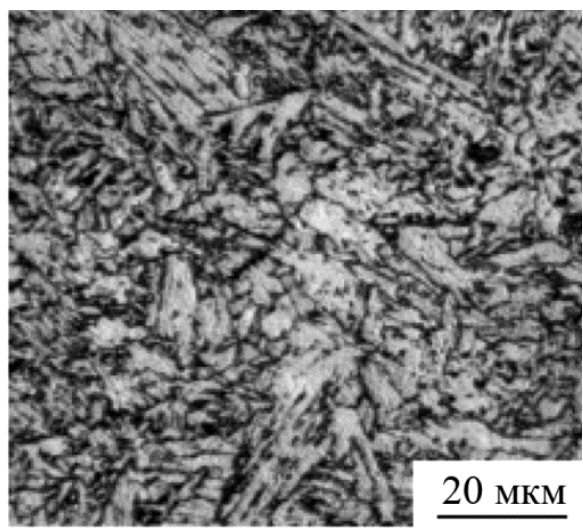

B

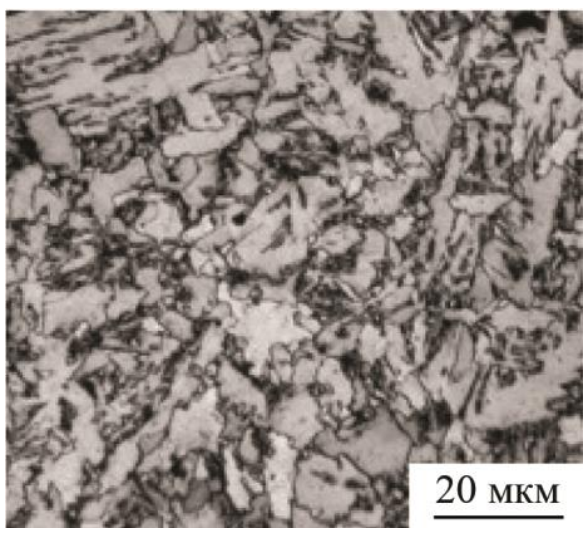

$\partial$

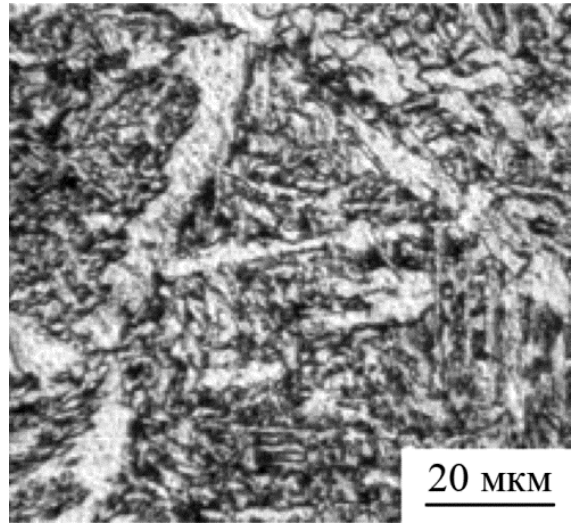

б

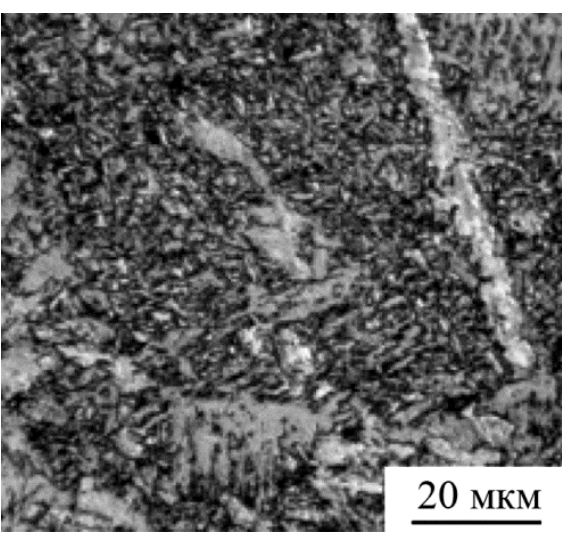

2

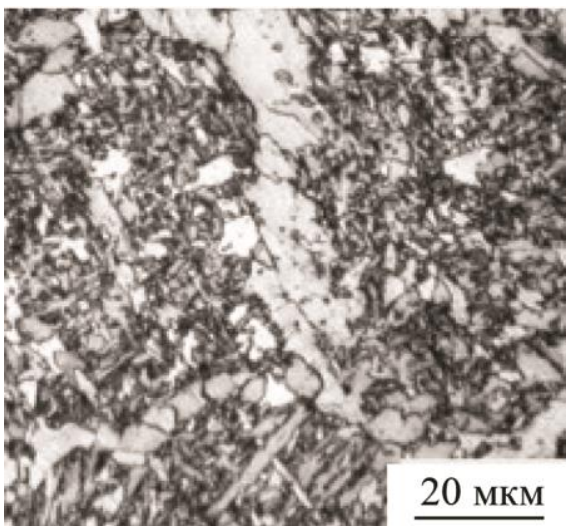

$e$

Рис. 3. Микроструктура зоны термического влияния $(a, 6, \partial)$ и сварного шва $(\sigma, z, e)$ образцов серии $3(a, \sigma), 4(в, 2)$ и $5(\partial, e)$

Таблица 4. Результаты испытаний на растяжение образцов сварных соединений и основного металла 09Г2С

\begin{tabular}{|c|c|c|c|c|c|}
\hline Серия & Режим сварки & $\sigma_{0,2}$, МПа & $\sigma_{\text {в }}, \mathrm{MПа}$ & $\delta, \%$ & $\psi, \%$ \\
\hline ОМ & - & 475 & 585 & 28,5 & 60,5 \\
\hline 3 & СМТ & 455 & 580 & 22,5 & 59,5 \\
\hline 4 & СМТ & 465 & 590 & 26,5 & 57,5 \\
\hline 5 & СПТ & 480 & 590 & 22,0 & 58,5 \\
\hline
\end{tabular}




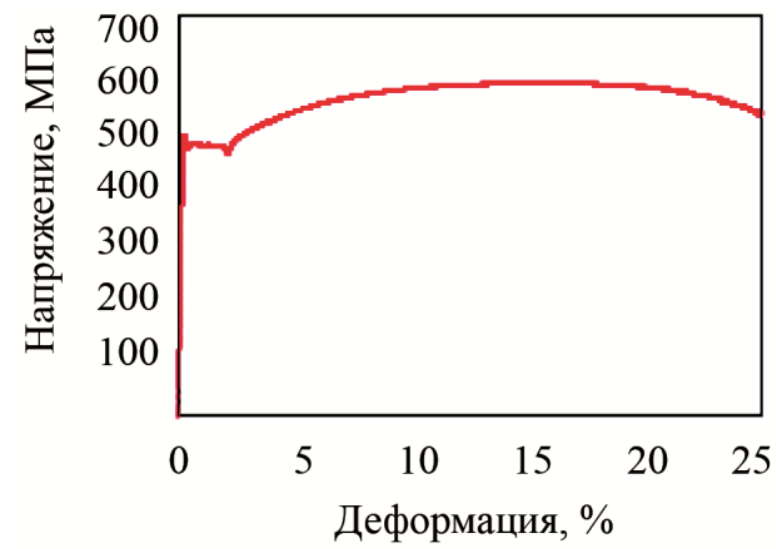

$a$

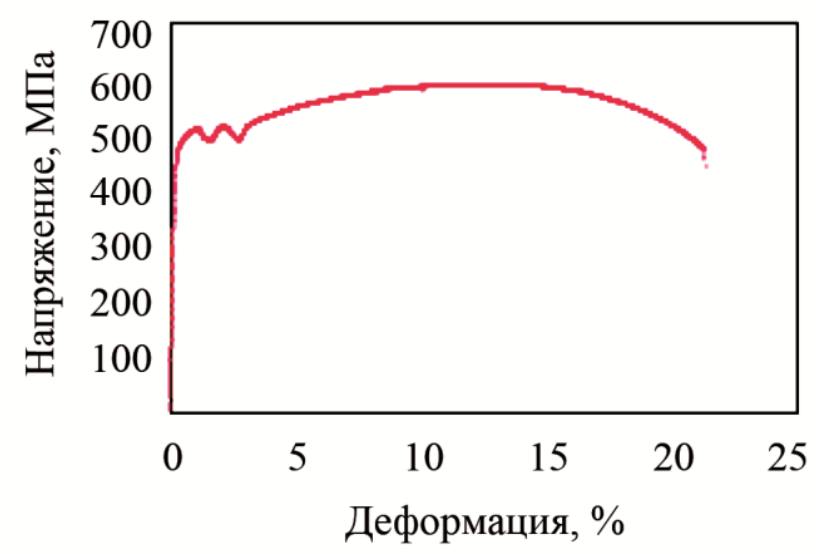

$\sigma$

Рис. 4. Типичные кривые растяжения основного металла $(a)$ и исследуемых сварных соединений (б), $t_{\text {исп. }}=20^{\circ} \mathrm{C}$

Приведенные в табл. 5 результаты ударных испытаний указывают на то, что понижение температуры испытаний от комнатной до минус $60{ }^{\circ} \mathrm{C}$ приводит к снижению ударной вязкости (KCV), а также значений $\mathrm{A}_{3}$ (работа зарождения трещины) и рассчитываемых по ним значений параметра динамической трещиностойкости $J_{\text {id. }}$ В наименьшей степени с понижением температуры испытаний снижаются значения $\mathrm{A}_{\mathrm{p}}$ (работы распространения трещины). О сохранении значительного запаса вязкости при температуре испытания минус $60{ }^{\circ} \mathrm{C}$ свидетельствует типично вязкий характер диаграммы нагружения (рис. 5 б) и присутствие определенной доли вязких ямок в изломе (рис. 6 г).

Разрушение ударных образцов основного металла при температурах 20 и $-60{ }^{\circ} \mathrm{C}$ происходило с образованием крупного расщепления в центральной части образцов. В образце, испытанном при комнатной температуре, формируются более выраженные боковые утяжки, что свидетельствует о значительном вкладе пластической деформации в процессе разрушения, относящегося к вязкому типу (рис. $6 a$, б). Разрушение основного металла образца, испытанного при температуре минус $60{ }^{\circ} \mathrm{C}$, происходило также преимущественно по вязкому микромеханизму, но при этом в изломе присутствовали участки с элементами хрупкого разрушения, классифицируемые как фасетки скола (рис. 6 в, г).

Таблица 5 - Характеристики ударной вязкости и динамической трещиностойкости металла сварного соединения из стали 09Г2С

\begin{tabular}{|c|c|c|c|c|c|c|c|}
\hline Серия & $\begin{array}{l}\text { Режим } \\
\text { сварки }\end{array}$ & $\begin{array}{c}\text { Место } \\
\text { вырезки }\end{array}$ & $t_{\text {исп. }},{ }^{\circ} \mathrm{C}$ & $\begin{array}{c}\mathrm{KCV}, \\
\mathrm{MД} / \mathrm{M}^{2}\end{array}$ & $\mathrm{~A}_{3}$, Дж & $\mathrm{A}_{\mathrm{p}}$, Дж & $\mathrm{J}_{\mathrm{id}}, \mathrm{MД} / \mathrm{M}^{2}$ \\
\hline \multirow{2}{*}{-} & \multirow{2}{*}{-} & \multirow{2}{*}{ OM } & 20 & 0,95 & 16,80 & 27,21 & 0,73 \\
\hline & & & -60 & 0,69 & 9,16 & 21,42 & 0,39 \\
\hline \multirow{2}{*}{3} & \multirow{2}{*}{ CMT } & \multirow{2}{*}{ 3ТВ } & 20 & 0,99 & 18,19 & 24,77 & 0,97 \\
\hline & & & -60 & 0,53 & 13,39 & 7,49 & 0,64 \\
\hline \multirow{2}{*}{4} & \multirow{2}{*}{ CMT } & \multirow{2}{*}{ ЗТВ } & 20 & 0,94 & 21,11 & 25,96 & 1,01 \\
\hline & & & -60 & 0,67 & 16,7 & 8,81 & 0,80 \\
\hline \multirow{2}{*}{5} & \multirow{2}{*}{ СПТ } & \multirow{2}{*}{ 3ТВ } & 20 & 0,93 & 10,31 & 19,26 & 0,70 \\
\hline & & & -60 & 0,39 & 13,55 & 4,00 & 0,64 \\
\hline
\end{tabular}


nttp:///ream-journal.or"]

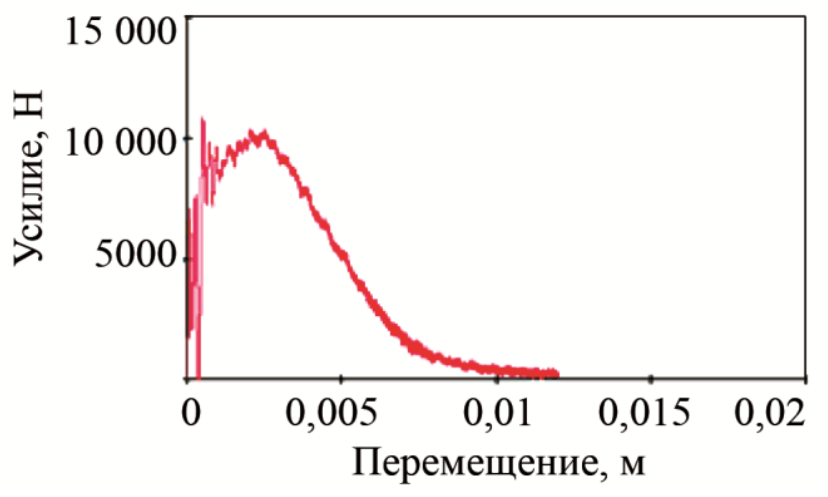

$a$

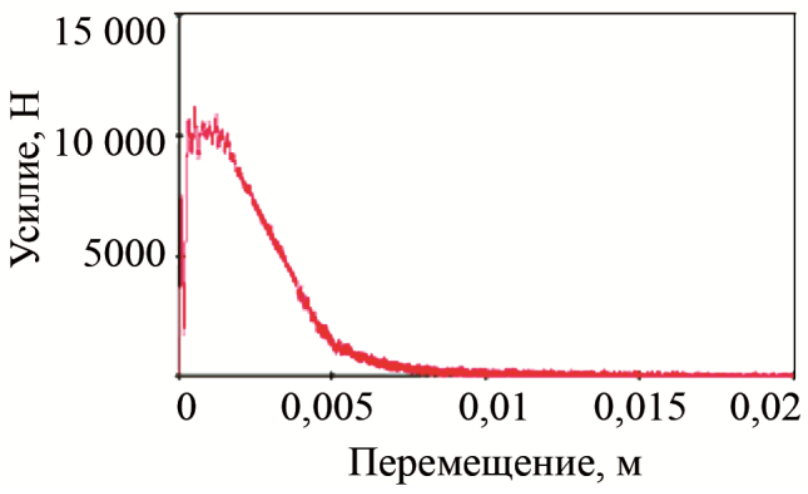

б

Рис. 5. Диаграммы ударного нагружения основного металла при температуре: $20^{\circ} \mathrm{C}(a)$ и $-60^{\circ} \mathrm{C}($ б)
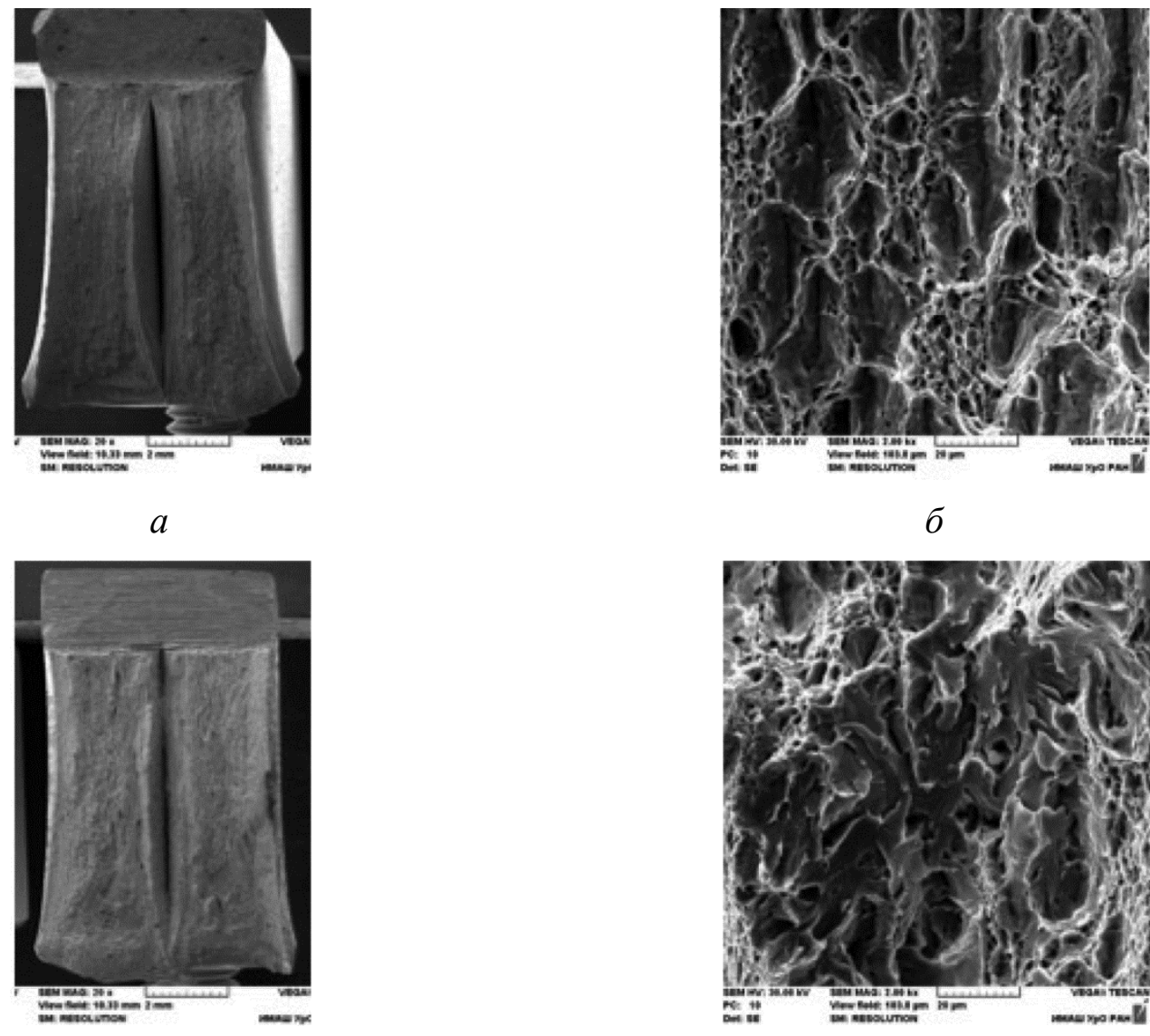

B

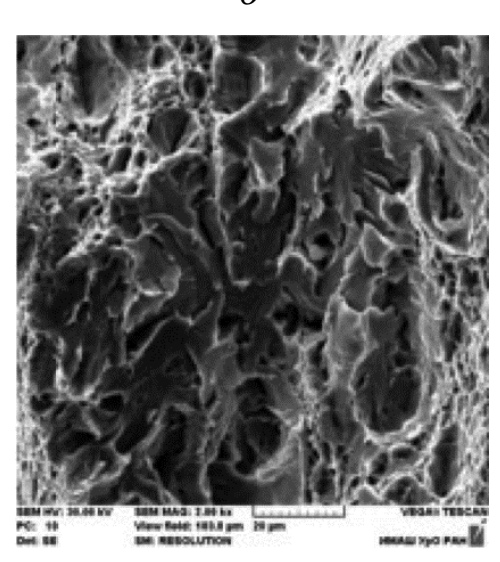

2

Рис. 6. Строение изломов ударных образцов основного металла после испытаний при температуре: $20^{\circ} \mathrm{C}(a, \sigma)$ и $-60^{\circ} \mathrm{C}(b, 2)$ 
На образцах металла ЗТВ серии 3 и 4, полученных методом СМТ, по сравнению с образцами из основного металла, ударная вязкость с понижением температуры уменьшается более заметно, но сохраняется на достаточно высоком уровне (табл. 5). На этих образцах выявлено резкое снижение значений работы распространения трещины $\mathrm{A}_{\mathrm{p}}-$ примерно в 3 раза. Следует отметить, что значения работы зарождения трещины $\mathrm{A}_{3}$ и рассчитываемые по ним параметры динамической трещиностойкости $\mathrm{J}_{\text {id }}$ металла ЗТВ, независимо от режима сварки, с понижением температуры испытаний от комнатной до $-60{ }^{\circ} \mathrm{C}$ снижаются не так заметно, как на образцах основного металла. Наименьшие значения $\mathrm{KCV}$ и $\mathrm{A}_{\mathrm{p}}$ выявлены на образцах ЗТВ сварного соединения, полученного на постоянном токе методом СПТ. Хрупкий скачок трещины на образцах серии 3 и 4, испытанных при температуре $-60{ }^{\circ} \mathrm{C}$, выражен в меньшей степени по сравнению с образцами серии 5, полученных по технологии СПТ (рис. 7 и 10).

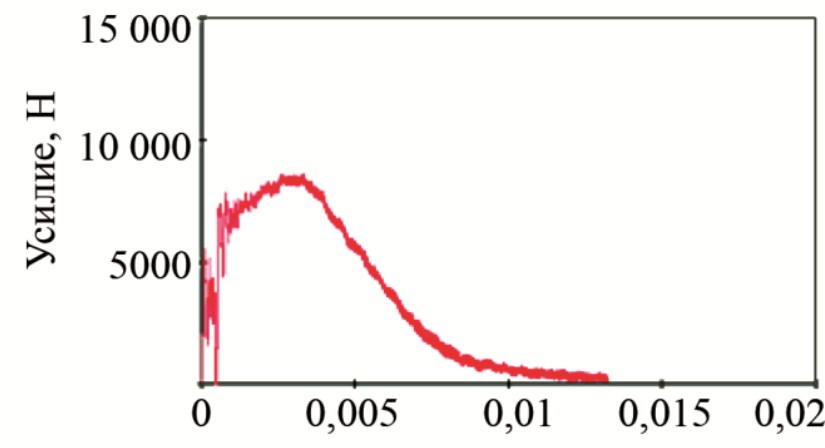

Перемещение, м

$a$

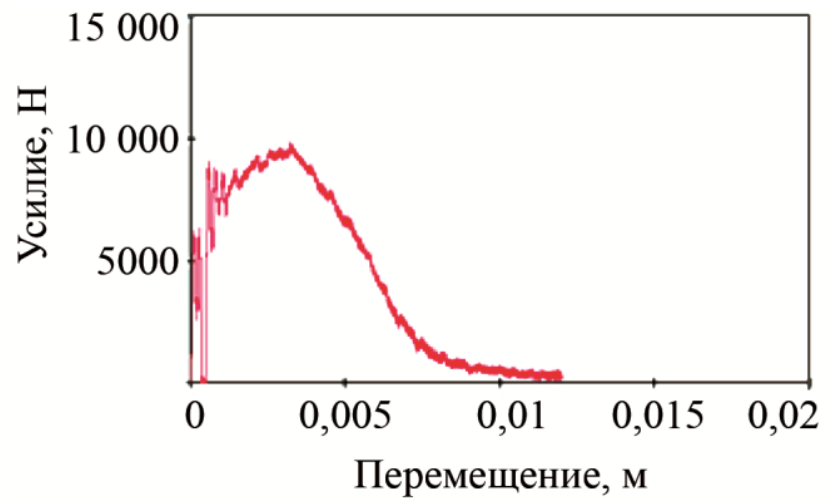

B

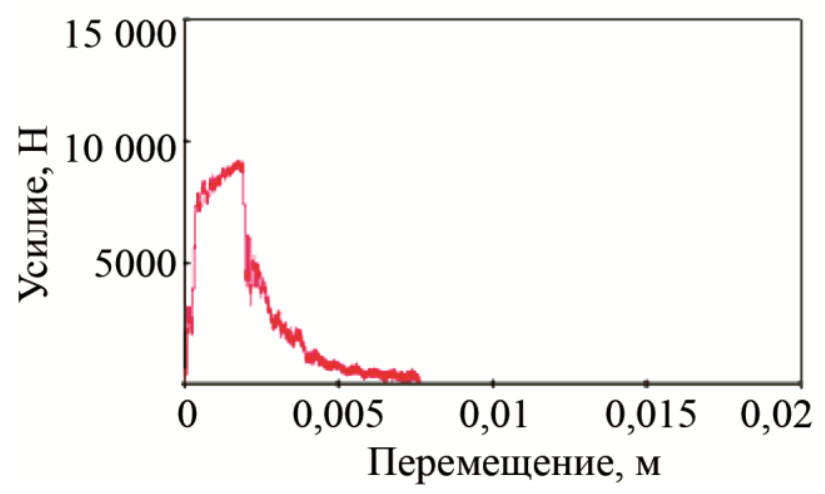

6

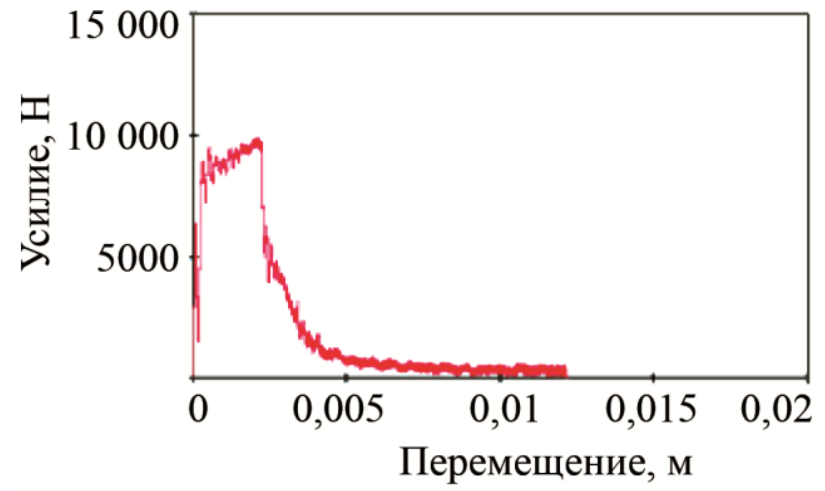

2

Рис. 7. Диаграммы ударного нагружения образцов 3ТВ серии $3(a, 6)$ и $4(6,2)$ при температуре: $20{ }^{\circ} \mathrm{C}(a, b)$ и $-60^{\circ} \mathrm{C}(\sigma, z) ; a, \sigma-3 \mathrm{~TB}$ образцов серии $3(\mathrm{CMT})$; в, 2 - ЗТВ образцов серии 4 (СМТ) 


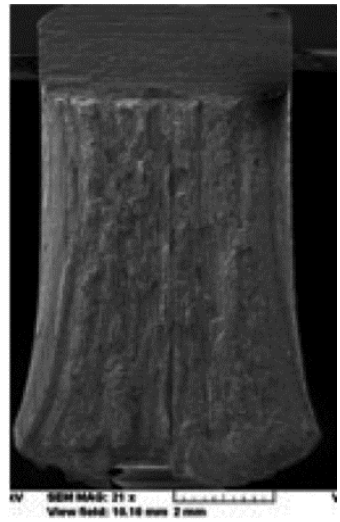

$a$

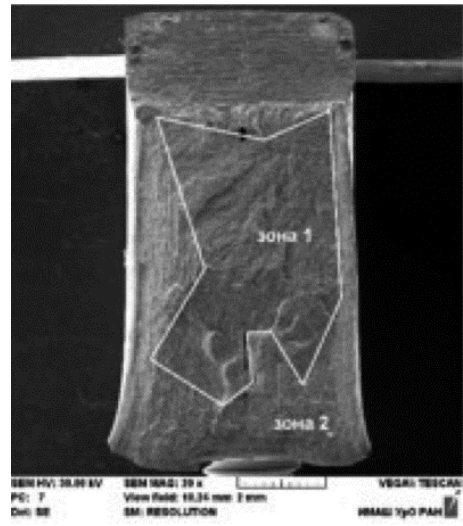

B

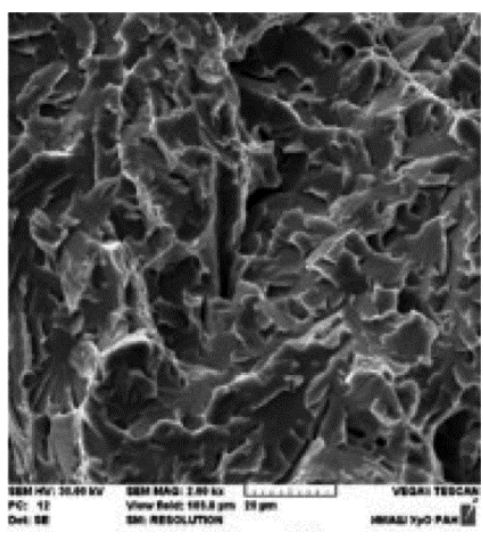

2 (зона 1)

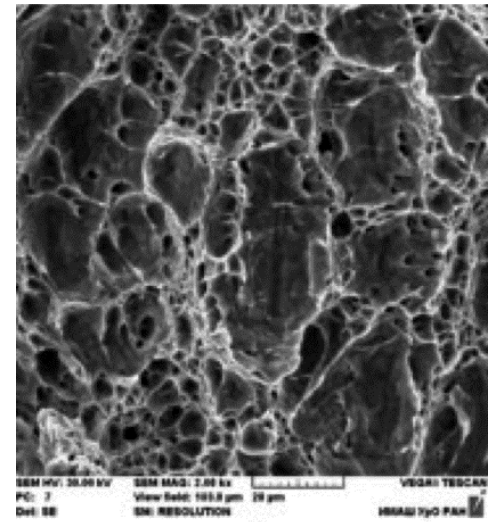

$\sigma$

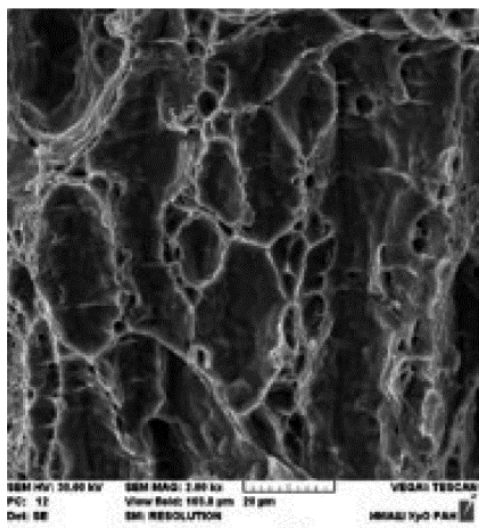

$\partial$ (зона 2)

Рис. 8. Строение изломов ударных образцов ЗТВ серии 3 (СМТ) после испытаний при температуре: $20{ }^{\circ} \mathrm{C}(a, \sigma)$ и $-60{ }^{\circ} \mathrm{C}(b-\partial)$

Изломы образцов серии 3 и 4 имеют выраженную утяжку, свидетельствующую о значительном вкладе пластической деформации в процесс разрушения. Эти образцы в ходе низкотемпературного ударного нагружения разрушаются с образованием смешанного излома. Центральная часть излома (зона 1) разрушается по хрупкому механизму квазискола, а периферийные участки излома (зона 2) - по вязкому механизму слияния микропор с образованием ямочного рельефа. В образце серии 3 доля хрупкого разрушения превосходит долю вязкого разрушения, а в образце серии 4 присутствуют сопоставимые по объему участки вязкого ямочного и хрупкого разрушения по механизму квазискола (рис. 8 и 9). В образцах серии 5 после ударных испытаний отсутствует боковая утяжка и излом имеет полностью хрупкий вид и состоит из фасеток квазискола (рис. 11).

На образцах серии 5 (СПТ) при комнатной температуре испытания разрушение идет по вязкому ямочному механизму (рис. 11 a). При температуре испытания $-60{ }^{\circ} \mathrm{C}$ реализуются наиболее низкие значения KCV (табл. 5), и процесс низкотемпературного разрушения развивается хрупко без выраженной боковой утяжки с образованием фасеток квазискола и вторичных трещин на всей поверхности разрушения (рис. 11 2). 


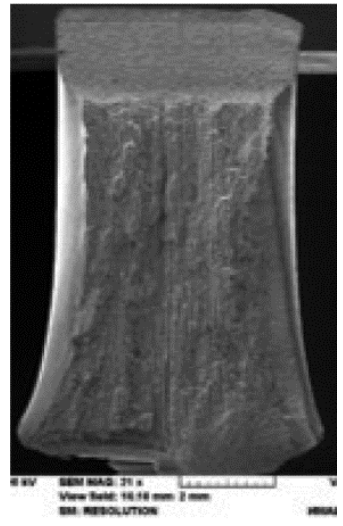

$a$

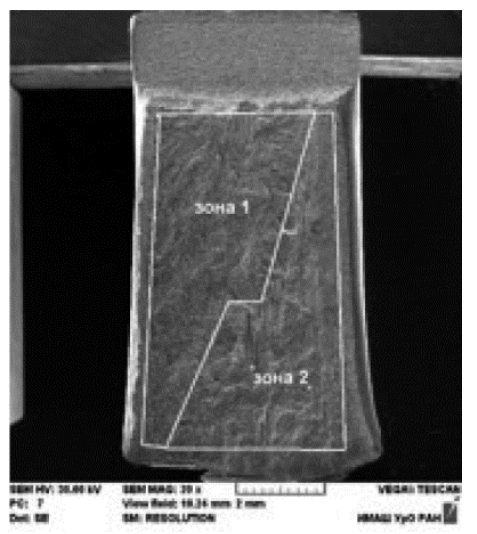

B

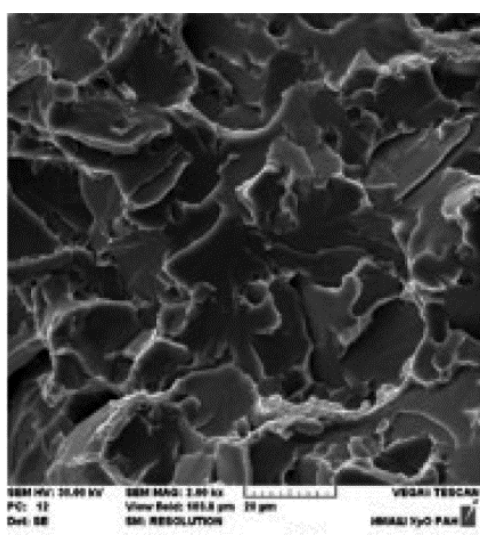

г (зона 1)

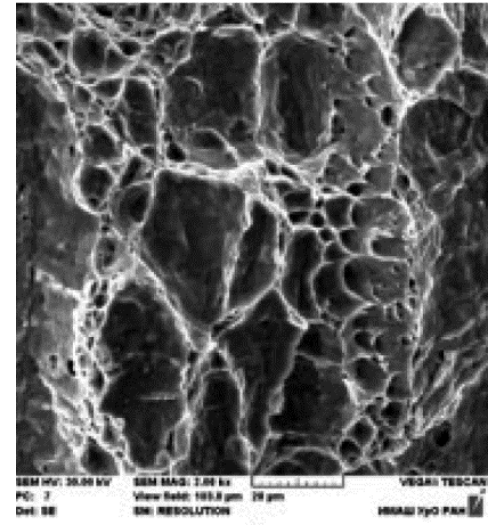

$\sigma$

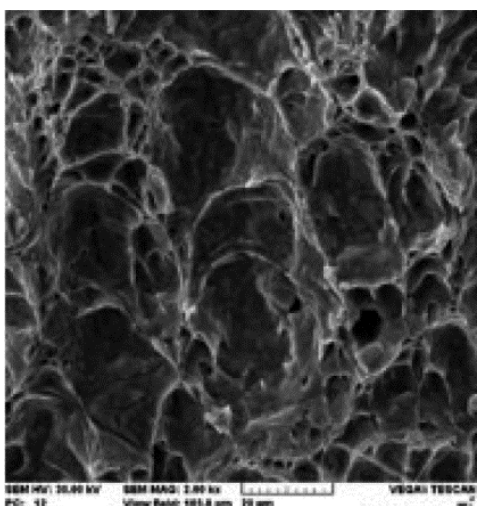

$\partial$ (зона 2)

Рис. 9. Строение изломов ударных образцов ЗТВ серии 4 (СМТ) после испытаний при температуре: $20^{\circ} \mathrm{C}(a, \sigma)$ и $-60{ }^{\circ} \mathrm{C}(b-\partial)$

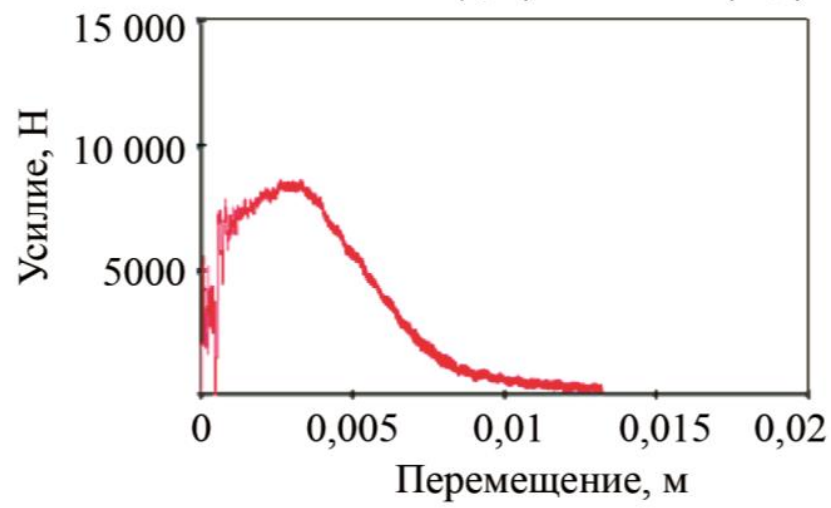

$a$

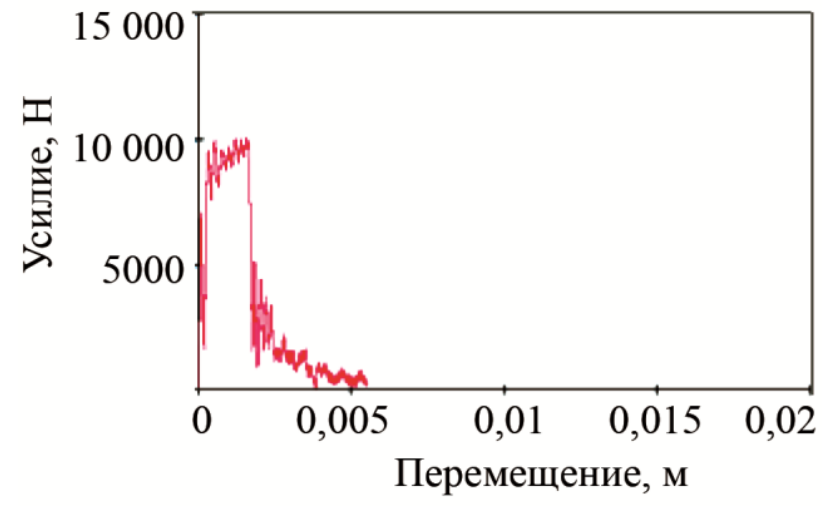

б

Рис. 10. Диаграммы ударного нагружения образцов ЗТВ серии 5 (СПТ) при температуре:

$$
20{ }^{\circ} \mathrm{C}(a) \text { и }-60{ }^{\circ} \mathrm{C}(\text { б) }
$$




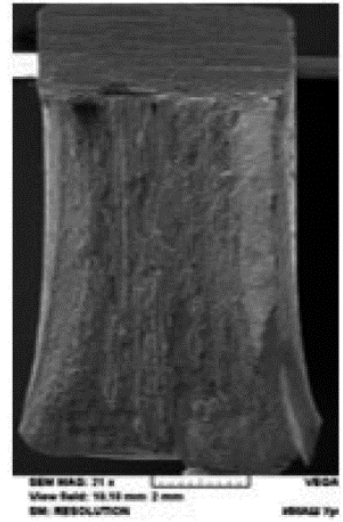

$a$

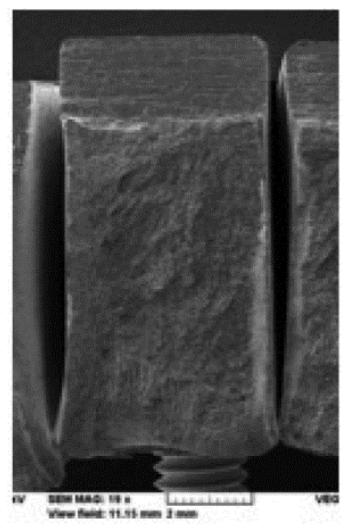

B

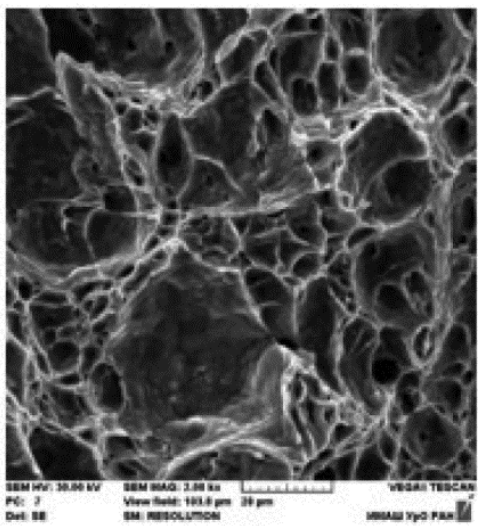

$\sigma$

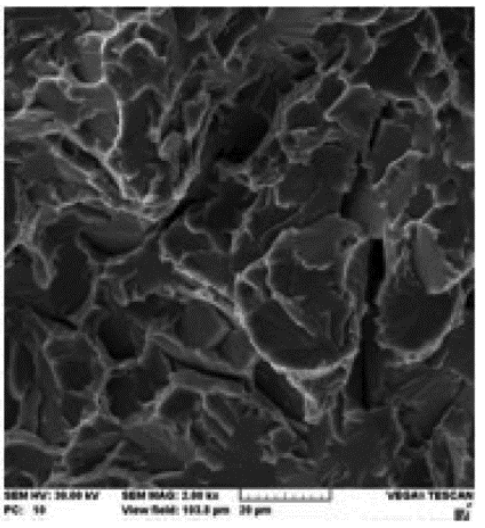

2

Рис. 11. Строение изломов ударных образцов ЗТВ серии 5 (СПТ) после испытаний при температуре: $20^{\circ} \mathrm{C}(a, \sigma)$ и $-60^{\circ} \mathrm{C}(b, 2)$

Результаты проведенных при комнатной температуре испытаний компактных СТ-образцов (тип 3 по ГОСТ 25.506-85) на статическую трещиностойкость представлены в табл. 6.

Таблица 6 - Значения статической трещиностойкости различных участков сварного соединения стали 09Г2С $\left(\mathrm{t}_{\text {исп. }}=20^{\circ} \mathrm{C}\right)$

\begin{tabular}{|c|c|c|c|}
\hline Серия & Режим сварки & Место вырезки & Кс, МПа· ${ }^{1 / 2}$ \\
\hline- & - & ОМ & 71,7 \\
\hline 3 & СМТ & 3ТВ & 79,8 \\
\hline 4 & СМТ & 3ТВ & 74,1 \\
\hline 5 & СПТ & 3ТВ & 71,3 \\
\hline
\end{tabular}

Установлено, что наиболее высокие значения статической трещиностойкости (вязкости разрушения) металла ЗТВ в условиях плоского напряженного состояния $\left(\mathrm{Kc}=79,8 \mathrm{MПа} \cdot \mathrm{M}^{1 / 2}\right)$ достигаются на образцах сварного соединения серии 3, полученного методом СМТ, а наименьшие $\left(\right.$ Кс $\left.=71,3 \mathrm{MПа} \mathbf{M}^{1 / 2}\right)$ - на образцах серии 5 , полученного методом СПТ. Показатели статической трещиностойкости металла ЗТВ серии 5 и основного металла практически находятся на одном уровне. Согласно представленным на рис. 12 фрактограммам участков статического роста трещины (зон долома) в ЗТВ и в основном металле разрушение всех изученных образцов носит вязкий ямочный характер. 


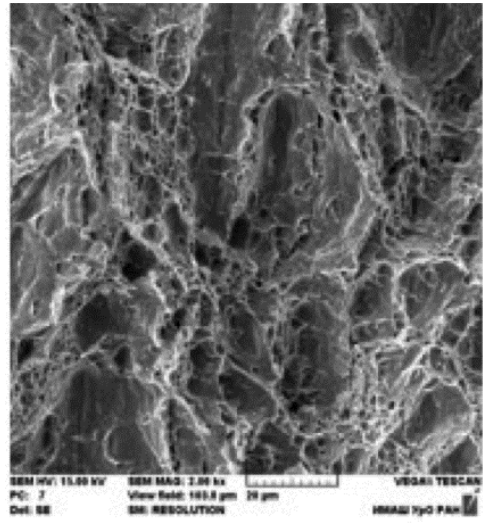

$a$

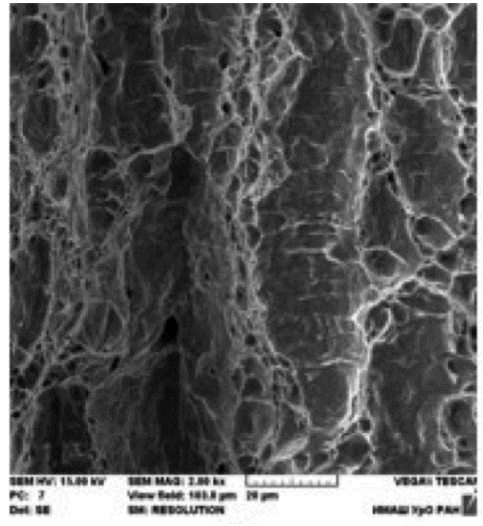

$\sigma$

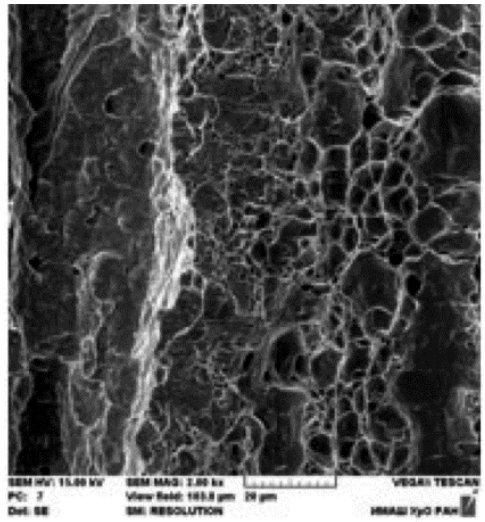

B

Рис. 12. Микростроение участков статического роста трещины в металле сварного соединения стали 09Г2С: $a$ - образцов ОМ; $\sigma$ - ЗТВ образцов серии 3 (СМТ), в- ЗТВ образцов серии 5 (СПТ)

Приведенные на рис. 13 результаты сравнительных циклических испытаний металла ЗТВ сварных соединений, полученных по технологиям СМТ и СПТ (серии 3 и 5 соответственно), свидетельствуют о том, что в области размаха значений $\Delta \mathrm{K}=23-26 \mathrm{MПа} \cdot \mathrm{M}^{1 / 2}$ образцы серии 3 характеризуются меньшими значениями скорости роста усталостной трещины по сравнению с образцами серии 5. Это указывает на преимущество в циклической трещиностойкости металла ЗТВ сварных соединей, полученных по технолгии СМТ по сравнению с СПТ на начальных стадиях роста усталостной трещины в области размаха значений $\Delta K=23-26$ МПа·м ${ }^{1 / 2}$. При дальнейшем продвижении усталостной трещины и соответствующем подрастании размаха коэффициента интенсивности напряжений в ее вершине в пределах значений $\Delta \mathrm{K}=27-33 \mathrm{MПа} \cdot \mathrm{M}^{1 / 2}$ скорость роста усталостной трещины на образцах серии 3 и 5 уравнивается и становится независимой от способа получения сварного соединения (рис. 13). Наблюдаемое изменение скорости роста усталостной трещины в зависимости от размаха значенеий $\Delta \mathrm{K}$ для металла ЗТВ сварных соединений, полученных методами СМТ и СПТ, хорошо согласуется с различием в рассчитанных по эксперментальным данным значений коэффиентов $\mathrm{m}$ и С уравнения Париса для линейного участка КДУР:

$$
\mathrm{dl} / \mathrm{dN}=\mathrm{C} \Delta \mathrm{K}^{\mathrm{m}} .
$$

Проведенный фрактографический анализ показал, что заметное различие в микростроении поверхности роста усталостной трещины в образцах металла ЗТВ серии 3 (СМТ) и 5 (СПТ) наблюдается только в начальной области испытаний, соответствующей достигнутым значениям $\Delta \mathrm{K}=23-26 \mathrm{MПа} \cdot \mathrm{M}^{1 / 2}$ (рис. $14 a$, б). На данном участке поверхности при циклических испытаниях в ЗТВ образцов серии 3 (СМТ) усталостные бороздки носят фрагментарный характер, а элементы рельефа разрушения существенно различаются по высоте, что может быть связано с реализацией смешанных циклических и статических мод нагружения [10]. На аналогичном участке циклического роста трещины в образцах серии 5 (СПТ) усталостные бороздки также отчетливо не выявляются, а элементы рельефа разрушения в виде плоских фасеток имеют незначительные перепады по высоте. 


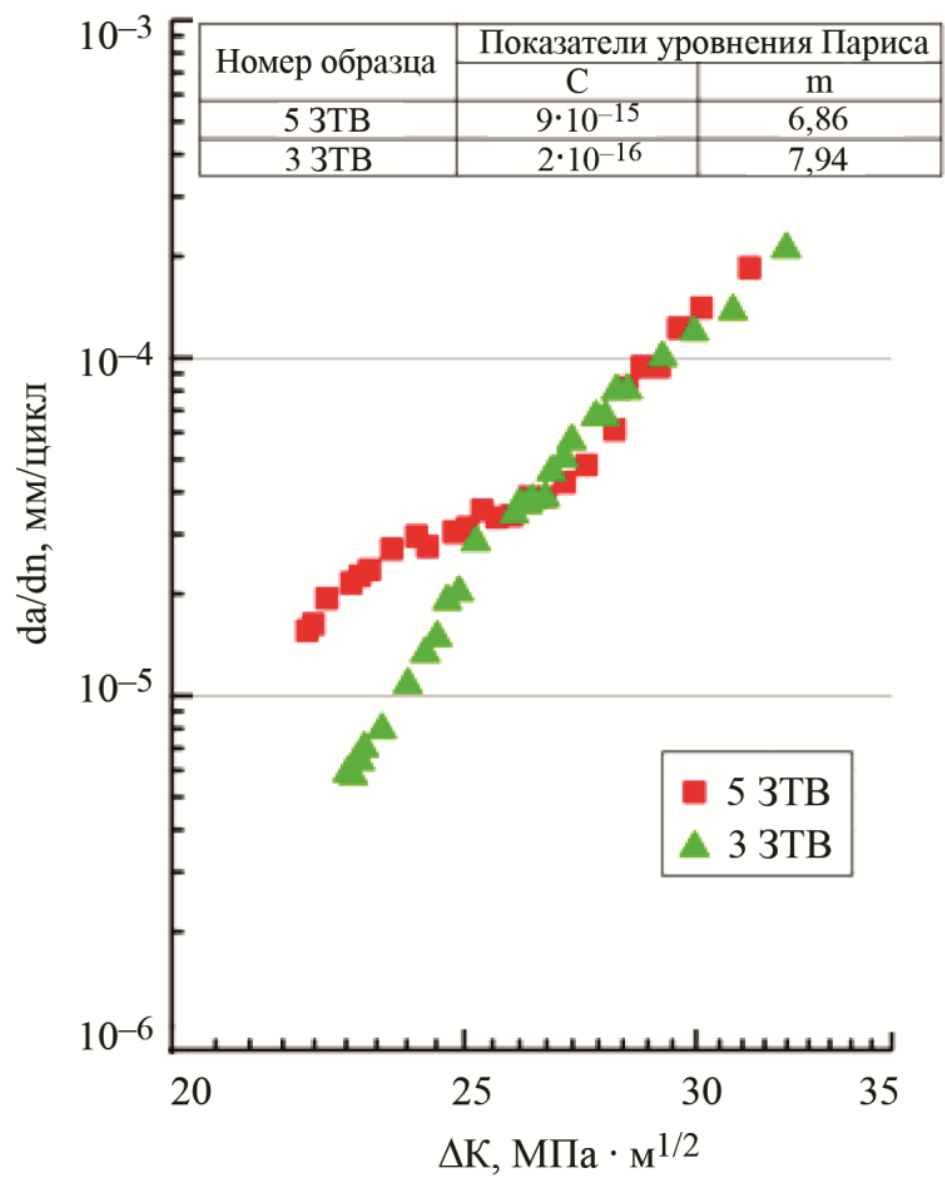

Рис. 13. Кинетические диаграммы усталостного разрушения металла ЗТВ сварных образцов серии 3 (СМТ) и серии 5 (СПТ)
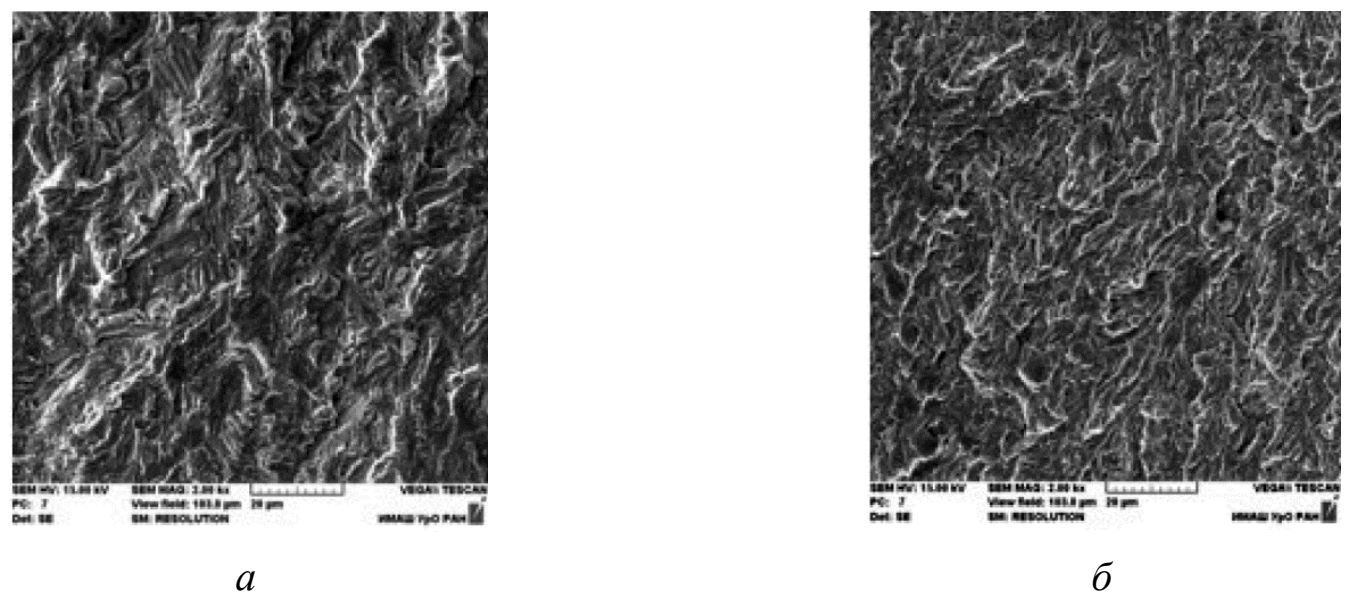

Рис. 14. Микростроение зоны циклического роста трещины в металле 3ТВ сварных образцов серии 3 - СМТ (a) и серии 5 - СПТ (б) в области значений $\Delta \mathrm{K}<26 \mathrm{MПа} \cdot \mathrm{M}^{1 / 2}$

В области более высоких значений $\Delta K=29-33 \mathrm{MПа} \cdot \mathrm{M}^{1 / 2}$, реализуемых в процессе циклических испытаний, при практически одинаковой скорости роста трещины, усталостные изломы имеют близкое микростроение, для которого характерно наличие более выраженных усталостных бороздок и вторичных трещин (рис. 15). 

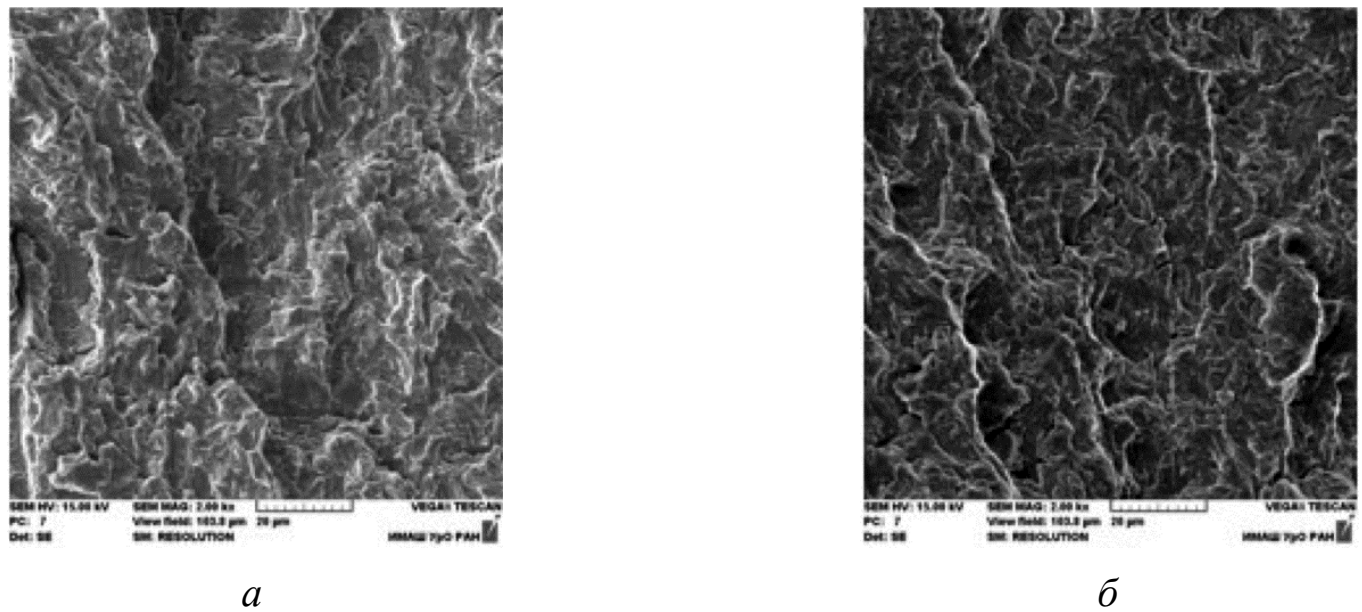

Рис. 15. Микростроение зоны циклического роста трещины в металле 3ТВ сварных образцов серии 3 - СМТ (a) и серии 5 - СПТ (б) в области значений $\Delta \mathrm{K}=27-33 \mathrm{MПа} \cdot \mathrm{M}^{1 / 2}$

Известно [14], что сопротивление металлических материалов усталостному разрушению в значительной мере зависит от величины и знака сформировавшихся в поверхностных слоях образцов остаточных напаряжений. В связи с этим для объяснения причин повышенной циклической трещиностойкости металла ЗТВ образцов серии 3 (СМТ), по сравнению с образцами серии 5 (СПТ), проведена оценка остаточных макронапряжений в центре СШ и в ЗТВ металла сварных соединений. При определении напряжений в ЗТВ образец в гониометре дифрактометра размещали таким образом, чтобы рентгеновский пучок падал на образец в непосредственной близости от сварного шва, но не попадал на него. Остаточные напряжения в ЗТВ определяли на расстоянии 5 мм по обе стороны от центра шва, ширина которого в зоне его усиления составляла около 10 мм, в корне шва - около 3 мм. Для всех исследуемых образцов зависимости $2 \theta_{\psi}$ от $\sin ^{2} \psi$ хорошо описываются линейной функцией, что свидетельствует об отсутствии градиента напряжений в поверхностном слое материала. Представленные в табл. 7 результаты свидетельствуют о том, что остаточные макронапряжения в центре шва для образцов серии 3 (CMT) являются сжимающими, что благоприятно сказывается на сопротивлении материала росту усталостных трещин. В ЗТВ происходит некоторое повышение напряжений сжатия, по сравнению с остаточными напряжениями в середине шва.

Таблица 7 - Макронапряжения в различных зонах сварного соединения

\begin{tabular}{|c|c|c|c|c|}
\hline \multirow{2}{*}{ Серия } & \multirow{2}{*}{$\begin{array}{c}\text { Режим } \\
\text { сварки }\end{array}$} & $\begin{array}{c}\text { ЗТВ (слева в 5 мм } \\
\text { от середины СШ) }\end{array}$ & $\begin{array}{c}\text { Середина } \\
\text { СШ }\end{array}$ & $\begin{array}{c}\text { ЗТВ (справа в 5 мм } \\
\text { от середины СШ) }\end{array}$ \\
\cline { 3 - 5 } & СМТ & -22 & -20 & -29 \\
\hline 3 & СПТ & -4 & 35 & 26 \\
\hline
\end{tabular}

Для образцов серии 5 (СПТ) в отличие от образцов серии 3 (СМТ) характерно наличие растягивающих остаточных напряжений поперек сварного шва, что создает благоприятные условия для зарождения и роста трещин. В металле ЗТВ с одной стороны от сварного шва остаточные напряжения растягивающие, так же, как и в сварном шве, а в ЗТВ, расположенной с другой стороны шва, остаточные напряжения являются сжимающими. В образцах серии 5 преобладают растягивающие остаточные макронапряжения, что способствует более ускоренному росту усталостных трещин при циклических испытаниях в области значений $\Delta \mathrm{K}<25 \mathrm{MПа} \cdot \mathrm{M}^{1 / 2}$ в металле ЗТВ сварного соединения, полученного по технологии СПТ. 


\section{4. Заключение}

1. Установлено, что импульсно-дуговая сварка по сравнению со сваркой на постоянном токе позволяет получить наиболее однородное распределение значений микротвердости по ширине всех зон сварного соединения стали 09Г2С. При этом дисперсность структурных элементов металла ЗТВ образцов серии 3 и 4 (СМТ) примерно в 1,5 раза выше по сравнению с аналогичным участком сварного соединения, полученного по технологии СПТ (образцы серии 5).

2. При испытаниях на растяжение сварных соединений, полученных методами СМТ и СПТ, выявлены скачки нагрузки, характерные для проявления эффекта прерывистой пластической деформации (эффект Портевена-Ле-Шателье). Показано, что при незначительном снижении характеристик пластичности сварного соединения по сравнению с основным металлом, прочностные свойства соответствуют основному металлу стали 09Г2С и это свидетельствует о достаточно высоком качестве сварного соединения.

3. Установлено, что в ЗТВ сварных соединений стали 09Г2С, полученных сваркой с модуляцией тока более высокие значения ударной вязкости $(\mathrm{KCV})$ и работы распространения трещины $\left(\mathrm{A}_{\mathrm{p}}\right)$ при пониженной температуре $\left(-60^{\circ} \mathrm{C}\right)$, по сравнению с соединениями, сваренными на постоянном токе. Выявлена взаимосвязь между характеристиками ударной вязкости образцов основного металла и ЗТВ, видом диаграмм ударного нагружения и фрактографическими особенностями микростроения изломов.

4. Показано, что высокие значения статической трещиностойкости (вязкости разрушения) металла ЗТВ в условиях плоского напряженного состояния $\left(\mathrm{Kc}=79,8 \mathrm{MПа} \cdot \mathrm{M}^{1 / 2}\right)$ достигаются на образцах сварного соединения серии 3, полученного методом СМТ, а наименьшие $\left(\right.$ Кс $\left.=71,3 \mathrm{MПа} \cdot \mathrm{M}^{1 / 2}\right)$ - на образцах серии 5 , полученной методом СПТ. Показатели статической трещиностойкости металла ЗТВ серии 5 и основного металла практически находятся на одном уровне

5. Сравнительные циклические испытания металла ЗТВ сварных соединений, полученных по технологиям СМТ и СПТ (серии 3 и 5 соответственно), свидетельствуют о том, что в области размаха значений $\Delta \mathrm{K}=23-26 \mathrm{MПа} \cdot \mathrm{M}^{1 / 2}$ на начальных стадиях роста усталостной трещины образцы серии 3 (CMT) характеризуются меньшими значениями скорости роста усталостной трещины по сравнению с образцами серии 5 (СПТ). Замедление роста усталостной трещины в сварных образцах серии 3, выполненных в режиме сварки с модуляцией тока, связано с тем, что в сварном шве и ЗТВ этих образцов формируются макронапряжения сжатия, а в образцах, выполненных на постоянном токе (серии 5), на всех участках сварного соединения преобладают ускоряющие рост трещин растягивающие макронапряжения.

6. При дальнейшем продвижении усталостной трещины в области значений $\Delta \mathrm{K}=$ = 27-33 МПа м $^{1 / 2}$ скорость ее роста на образцах серии 3 и 5 уравнивается и становится независимой от способа получения сварного соединения. Заметное различие в микростроении усталостного излома образцов металла ЗТВ серий 3 (СМТ) и 5 (СПТ) наблюдается только на начальных участках поверхности роста усталостной трещины, соответствующей достигнутым значениям $\Delta \mathrm{K}=23-26 \mathrm{MПа} \cdot \mathrm{M}^{1 / 2}$.

\section{Благодарность}

Авторы выражают благодарность с.н.с., к.ф.-м.н. С.М. Задворкину и м.н.с. Л.С. Горулевой за помощь в определении остаточных напряжений рентгеновским методом, а также м.н.с. С. В. Кутеневой за проведение металлографического анализа.

Работа выполнена за счет средств РНФ, проект № 16-19-10010. 


\section{Литература}

1. Грабин В. Ф., Денисенко А. В. Металловедение сварки низко- и среднелегированных сталей. - Киев : Наукова думка, 1978. - 256 с.

2. Лившиц Л. С., Хакимов А. Н. Металловедение сварки и термическая обработка сварных соединений. - 2-е изд., перераб. и доп. - М.: Машиностроение, 1989. - 336 с.

3. Махутов Н. А., Лыглаев А. В., Большаков А. М. Хладостойкость (метод инженерной оценки) / ИФТПС им. В.П. Ларионова СО РАН; отв. ред. М. П. Лебедев, Ю. Г. Матвиенко. Новосибирск : Изд-во СО РАН, 2011. - 195 с.

4. Горицкий В. М. Применение характеристик ударной вязкости в инженерной практике. М. : Металлургиздат, 2016. - 304 с.

5. Формирование структуры и свойств сварных соединений в условиях регулируемого тепловложения при импульсно-дуговой сварке / Ю. Н. Сараев, И. М. Полетика, А. В. Козлов, Е. Г. Хомченко // Физическая мезомеханика. - 2005. - Т. 8 (Спец. выпуск). - С. 137-140.

6. Влияние технологий сварки на физико-механические характеристики металла различных зон сварных соединений низколегированной стали / Э. С. Горкунов, Ю. Н. Сараев, С. М. Задворкин, Е. А. Путилова // Вопросы материаловедения. - 2015. - № 1 (81). C. $120-126$.

7. Повышение эксплуатационных свойств металлоконструкций для работы в условиях низких климатических температур методами адаптивной импульсно-дуговой наплавки / Ю. Н. Сараев, С. В. Гладковский, Н. И. Голиков, В. Е. Веселова // Сварочное производство. 2015. - № 11. - C. 33-40.

8. Properties of the Welded Joints of Manganese Steel Made by Low-Frequency Pulsed Arc Welding / Yu. N. Saraev, V. P. Bezborodov, S. V. Gladovskii, N. I. Golikov // Russian Metallurgy. 2017 - No. 4. - P. 287-292. - DOI: 10.1134/S0036029517040206

9. Saraev Yu. N., Bezborodov V. P., Gladovskiy S. V., Golikov N. I. Improving the reliability of metallic structures in service in the conditions with low climatic temperatures by efficient application of advanced methods of modification of the zone of the welded joint // Welding International, 2017. - Vol. 31, No 8, pp. 631-636. DOI: 10.1080/09507116.2017.1307512

10. Ботвина Л. Р. Разрушение. Кинетика, механизмы, общие закономерности / Ин-т металлургии и материаловедения им. А. А. Байкова РАН. - М. : Наука, 2008. - 334 с.

11. Терентьев В. Ф. Усталостная прочность металлов и сплавов. - М. : Интермет Инжиниринг, 2002. - 288 с. - ISBN 5-89594-076-5.

12. Русаков А. А. Рентгенография металлов - М. : Атомиздат, 1977. - 480 с.

13. Pugacheva N. B., Michurov N. S., Trushina E. B. Peculiarities of the structure of welded aluminum alloy joints // Diagnostics, Resource and Mechanics of materials and structures. - 2015. Iss. 5. - P. 58-71. - URL: http://dream-journal.org/issues/2015-5/2015-5_43.html

14. Х Хоникомб Р. Пластическая деформация металлов. - М. : Мир, 1972. - 408 с. 